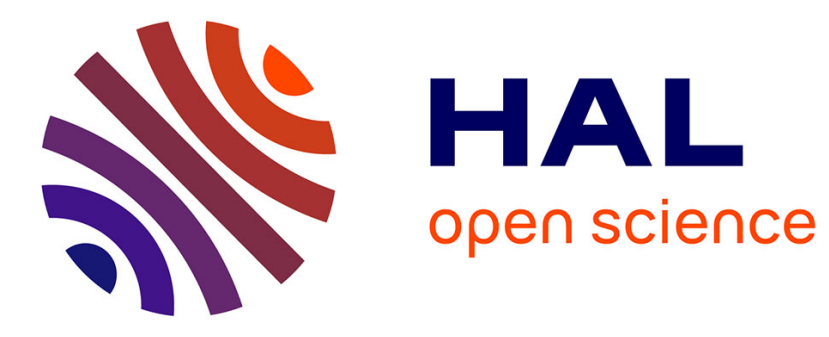

\title{
A straightforward route to spiroketals
}

Nicolas Guisot, B. Ouled-Lahoucine, Isabelle Canet, Marie-Eve Sinibaldi

\section{To cite this version:}

Nicolas Guisot, B. Ouled-Lahoucine, Isabelle Canet, Marie-Eve Sinibaldi. A straightforward route to spiroketals. Tetrahedron Letters, 2007, 48, pp.8511-8513. 10.1016/j.tetlet.2007.09.151 . hal00246537

\section{HAL Id: hal-00246537 https://hal.science/hal-00246537}

Submitted on 7 Feb 2008

HAL is a multi-disciplinary open access archive for the deposit and dissemination of scientific research documents, whether they are published or not. The documents may come from teaching and research institutions in France or abroad, or from public or private research centers.
L'archive ouverte pluridisciplinaire $\mathbf{H A L}$, est destinée au dépôt et à la diffusion de documents scientifiques de niveau recherche, publiés ou non, émanant des établissements d'enseignement et de recherche français ou étrangers, des laboratoires publics ou privés. 


\title{
A straightforward route to spiroketals
}

\author{
Nicolas Ardes-Guisot, ${ }^{\dagger}$ Bani Ouled-Lahoucine, Isabelle Canet* \\ and Marie-Eve Sinibaldi*
}

SEESIB, UMR 6504, Université Blaise Pascal, 63177 Aubière Cedex, France

\begin{abstract}
A straightforward route to 1,7-dioxa-, 1,4,7-trioxa- and 1,4,7,10-tetraoxaspiro[5.5]undecanes, starting from commercially available 3-chloro-2(chloromethyl)prop-1-ene, is described.
\end{abstract}

The spiroketal moiety is found as a structural part in the skeleton of the natural products of varying complexity. Because of importance of the pharmacological properties related to these compounds, many strategies have been devoted to this bicyclic system. ${ }^{1}$ Most methods lie on an acid-catalyzed cyclization of a linear dihydroxyketone or a pre-assembled hemiacetal, the novelty arising from the access to these key precursors. This cyclization approach is particularly suitable when the target spiroketal possesses a 'thermodynamic' configuration. ${ }^{2}$ Fortunately, this is the case with most spiroketals in nature, although notable exceptions do exist. ${ }^{3}$

In this Letter, the scope of a stereoselective and versatile three-step approach towards the construction of spiroketal unit $\mathbf{1}$ is presented, starting from commercially available 3-chloro-2-(chloromethyl)prop-1-ene 2 (Scheme 1). Indeed, despite the efficiency of our recently reported approaches to $\mathbf{1}$, the first one-based upon the alkylation of acetone $N, N$-dimethylhydrazone ${ }^{4}$ - only allowed the synthesis of structures $\mathbf{1 b}$ while the second - using condensation on 1,3-dichloroacetone- $O$-benzyloxime-led only to the incorporation of two supplementary heteroatoms in the cycles, such as structure $1 \mathbf{a}^{5}$ These results prompted us to consider a new pathway, described herein, that proved to be very effective not only for the

Keywords: Spiroketals; Spirodioxanes; Cyclization; Substitution.

* Corresponding authors. Tel.: +33 473407 875; fax: +33 473407717

(I.C.); tel.: +33 473405 284; fax: +33473407717 (M.-E.S.); e-mail addresses: isabelle.canet@univ-bpclermont.fr;m-eve.sinibaldi-troin@ univ-bpclermont fr

${ }^{\dagger}$ Present address: ICMMO, Laboratoire de Chimie Organique Multifonctionnelle, UMR 8282, Université Paris-Sud XI, 91400 Orsay, France.

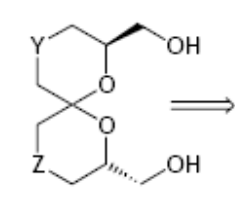

1a $Y=Z=0$

1b $Y=\mathrm{Z}=\mathrm{CH}_{2}$

1c $\mathrm{Y}=\mathrm{O}, \mathrm{Z}=\mathrm{CH}_{2}$

Scheme 1.

construction of 1a,b but also for the never reported so far compound 1c.

We first investigated the synthesis of 1a (Scheme 2). ${ }^{6}$ Our pathway started by the double substitution of 3chloro-2-(chloromethyl)prop-1-ene 2 by $(S)$-solketal 3

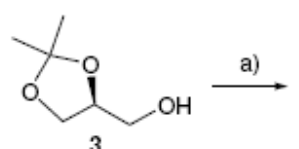

3

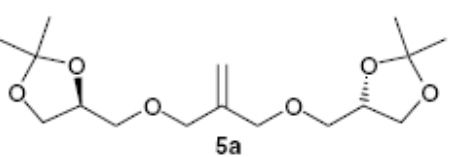

5 a<smiles>CC(C)OC[C@H]1COC[C@@]2(COC[C@@H](CO)O2)O1</smiles>

1 a

Scheme 2. Reagents and conditions: (a) $\mathrm{NaH}$ ( 3 equiv), THF, then $\mathbf{2}$, rt then reflux, $18 \mathrm{~h}, 93 \%$; (b) $\mathrm{O}_{3}, \mathrm{DCM},-78^{\circ} \mathrm{C}$ then $\mathrm{Me}_{2} \mathrm{~S},-78^{\circ} \mathrm{C}$ to rt, $88 \%$; (c) Amberlyst ${ }^{\infty} 15$, MeOH, reflux, 12 h, $79 \%$. 
to give alkene 5a. This step could be very efficiently achieved, by heating to reflux a mixture of alkene 2 and the anion of $\mathbf{3}$, generated by the action of sodium hydride, in THF. Subsequent ozonolysis of $\mathbf{5}$ a provided ketone $\mathbf{6 a}$ in a $88 \%$ yield. Finally, a simple exposure of ketone 6a to Amberlyst ${ }^{\circledR} 15$ in $\mathrm{MeOH}$ effected the desired spiroketalization in a $79 \%$ yield.

Using our novel strategy, enantiomerically pure (2R,6S,8R)-1,4,7,10-tetraoxaspiro[5.5] undecane $1 \mathbf{1}^{7}$ was obtained in three steps in a $64 \%$ overall yield. This synthesis could be favourably compared to those previously achieved in our laboratory (four steps and $19 \%$ yield, ${ }^{6 a}$ two steps and $55 \%$ yield $^{5}$ ).

The next challenge was to achieve the preparation of $\mathbf{1} \mathbf{b}^{8}$ via alkylation of dichloro compound 2 . The trimethylmethane dianion prepared by double deprotonation of methylpropene using a mixture of $n$-BuLi and TMEDA or tert-BuOK, ${ }^{9}$ is known to permit the introduction, at once and in a one-step procedure, of two electrophiles leading to polyfunctionalised molecules. However, one observes mainly a decomposition of the lithiated species before the reaction. Therefore, to circumvent this problem, milder Barbier-type reaction conditions have been developed involving lithium metal and a catalytic amount of an arene to achieve a chlorine-lithium exchange on $2 .^{10}$

We first applied this method to prepare spiroketal $\mathbf{1 b}$. Our attempts were based on the arene-catalysed lithiation of $\mathbf{2}$, followed by alkylation with an halogenated derivative of 1,2-O-isopropylidene-1,2,4-butanetriol 4 . However, even with varying the experimental conditions - temperature, base, chelating agent (naphthalene, TMEDA), alkylating agent (bromo or iodo derivative) our attempts were unsuccessful and led mainly to self-alkylation of the halogenated compound 4 . We then focused on the halopolycarbon homologation, ${ }^{11}$ realised by adding a THF solution of the Grignard reagent of $4 \mathbf{a}^{12}$ to a cooled well-stirred solution of dihalide $\mathbf{2}$ in the presence of a catalytic amount of lithium tetrachlorocuprate (Scheme 3).

After optimisation of the experimental conditions, alkene $\mathbf{5 b}$ was obtained in a $73 \%$ yield. Low temperature ozonolysis of $\mathbf{5 b}$ provided ketone $\mathbf{6} \mathbf{b}$, which was submit-<smiles>C=C(CCCC1COC(C)(C)O1)CCCC1COC(C)(C)O1</smiles><smiles>CC1(C)OC[C@@H](CCCC(=O)CCCC2C[C@H](CO)C(C)(C)O2)O1</smiles>

Scheme 3. Reagents and conditions: (a) (i) $\mathrm{Mg}$, THF, rt then reflux, $3 \mathrm{~h}$ (ii) $2, \mathrm{THF},-78^{\circ} \mathrm{C}$, (iii) $\mathrm{Li}_{2} \mathrm{CuCl}_{4}, \mathrm{THF},-78^{\circ} \mathrm{C}$ to $\mathrm{rt}, 18 \mathrm{~h}, 73 \%$; (b) $\mathrm{O}_{3}, \mathrm{DCM},-78^{\circ} \mathrm{C}$ then $\mathrm{Me}_{2} \mathrm{~S},-78{ }^{\circ} \mathrm{C}$ to $\mathrm{rt}, 79 \%$; (c) Amberlyst ${ }^{\circ}$ $15, \mathrm{MeOH}$, reflux, $12 \mathrm{~h}, 83 \%$. ted to an acidic deprotection-cyclization sequence by classical treatment with Amberlyst ${ }^{\circledR} 15$ in $\mathrm{MeOH}$, affording spiroketal $\mathbf{1 b}$ in a $83 \%$ yield.

Starting from 3-chloro-2(chloromethyl)propene 2, (2S, $6 S, 8 S$ )-1,7-dioxaspiro[5.5]undecane $\mathbf{1} \mathbf{b}^{7}$ was obtained in a $48 \%$ overall yield over three steps.

Our final aim was to examine the validity of our strategy to access the 1,4,7-trioxaspiro[5.5] undecane moiety. Few examples of the synthesis of this kind of skeleton were described in the literature $\mathrm{e}^{6,13}$ but, so far, 1,4,7-trioxaspiro[5.5] undecane-2,8-diyldimethanol 1c has never been reported.

In this aim, it was first necessary to develop a process to achieve a selective monoalkylation of 2 . In light of former results, we decided to investigate the synthesis of intermediate 7 , containing an oxygenated arm, precursor of the 1,4-dioxolane cycle of 1c (Scheme 4). After an extensive study of the monosubstitution conditions of $\mathbf{2}$ by the anion of solketal 3, we finally obtained monoadduct 7 cleanly in a $68 \%$ isolated yield using $\mathrm{KOH}$ in the presence of 18 -crown-6, in toluene ${ }^{14}$ at $70^{\circ} \mathrm{C}$.

In our initial attempts of alkylation of 7, the use of an arene-catalysed lithiation (Barbier-type conditions) was unsuccessful. Monoalkylation of 7 , using the previously dialkylation conditions - Grignard reagent of $4 \mathbf{a}$ in the presence of $\mathrm{Li}_{2} \mathrm{CuCl}_{4}$-failed to give the desired product and led mainly to alkylation of $\mathbf{4 a}$ on itself. Olsen et al., ${ }^{15}$ depicted the alkylation of 1,2-O-isopropylidene4-chloro-1,2-butanediol with 2-benzamido-3-bromo4-hydroxybut-2-enoic-acid $\gamma$-lactone via dialkyl cuprate reagents. In our case, the use of copper iodide to form the cuprate derivative of $\mathbf{4 a}$, via its lithiated form, allowed us to obtain alkene $\mathbf{5}$ c albeit in a $30 \%$ yield. $^{16}$ Further work on the development of the reaction to improve this yield is now under investigations. Meanwhile, the ozonolysis of $\mathbf{5} \mathbf{c}$, followed by a one-pot deprotection/cyclization process on the generated ketone $\mathbf{6 c}$,
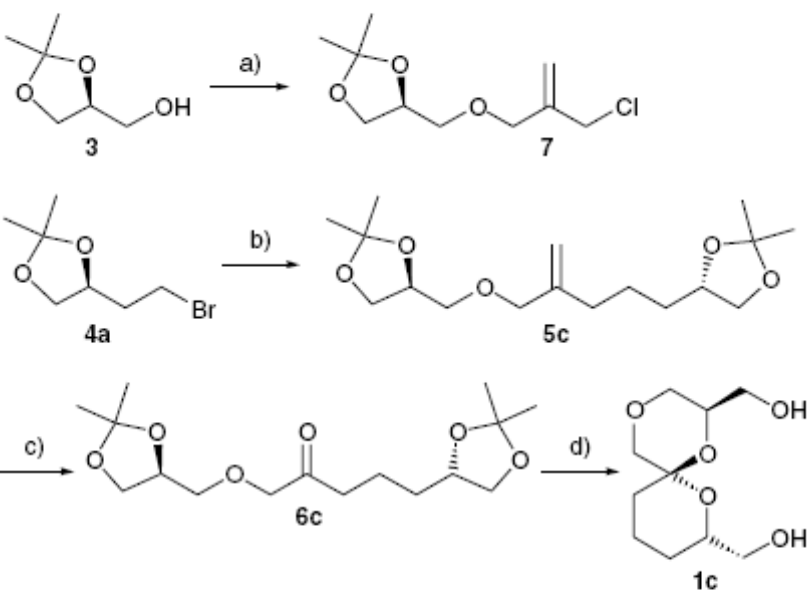

Scheme 4. Reagents and conditions: (a) (i) $\mathrm{KOH}$, toluene, $70^{\circ} \mathrm{C}, 1 \mathrm{~h}$, (ii) $2,48 \mathrm{~h}, 68 \%$; (b) (i) tert-BuLi, THF, $-78^{\circ} \mathrm{C}, 1 \mathrm{~h} 30 \mathrm{~min}$, (ii) CuI, $-40{ }^{\circ} \mathrm{C}, 1 \mathrm{~h}$ then $7,-65^{\circ} \mathrm{C}$ to $\mathrm{rt}, 30 \%$; (c) $\mathrm{O}_{3}, \mathrm{DCM},-78^{\circ} \mathrm{C}$ then $\mathrm{Me}_{2} \mathrm{~S},-78{ }^{\circ} \mathrm{C}$ to rt, $72 \%$; (d) Amberlyst ${ }^{\circ} 15$, $\mathrm{MeOH}$, reflux, $12 \mathrm{~h}, 83 \%$. 
afforded $1 \mathbf{c}^{17}$ in a good yield of $60 \%$ in two steps (Scheme 4).

Finally, the novel (2R,6S,8S)-1,4,7-trioxaspiro[5.5] undecane 1c was obtained in three steps in a $12 \%$ non optimized overall yield.

In conclusion, the methodology described herein has proven to be very efficient for the construction of 1,7-dioxa-, 1,4,7-trioxa- and 1,4,7,10-tetraoxaspiro[5.5]undecane cores. By this way, the synthesis of spiroketals 1a,b were notably improved and the first synthesis of spiroketal 1c has been realized. Its broad applicability, as well as the potential to further produce elaborated spiroketals, make this three step methodology a valuable tool for the synthesis of natural products containing highly functionalised spiroketal moieties.

\section{Acknowledgement}

N.A.-G. acknowledges the 'Centre National de la Recherche Scientifique' for a postdoctoral fellowship.

\section{References and notes}

1. For reviews see: (a) Mead, K. T.; Brewer, B. N. Curr. Org. Chem. 2003, 7, 227-256; (b) Francke, W.; Kitching, W. Curr. Org. Chem. 2001, 5, 233-251; (c) Jacobs, M. F.; Kitching, W. Curr. Org. Chem. 1998, 2, 395-436; (d) Perron, F.; Albizati, K. F. Chem. Rev. 1989, 89, 16171661; (e) Boivin, T. L. B. Tetrahedron 1987, 43, 3309-3362.

2. For a review of the different spiroketal configurations found in nature, see Ref. $1 \mathrm{~b}$. For a more detailed discussion of the anomeric effect see: Deslongchamps, P. In Organic Chemistry Series; Baldwin, J. E., Ed.; Stereoelectronic Effects in Organic Chemistry; Pergamon Press: Oxford, 1983; Vol. 1, pp 5-20.

3. Aho, J. E.; Pihko, P. M.; Rissa, T. K. Chem. Rev. 2005, $105,4406-4440$.

4. Tursun, A.; Canet, I.; Aboab, B.; Sinibaldi, M.-E. Tetrahedron Lett. 2005, 46, 2291-2294.

5. Goubert, M.; Canet, I.; Sinibaldi, M.-E. Eur. J. Org. Chem. 2006, 21, 4805-4812.

6. For previously reported synthesis of 1a see: (a) Lemaire, M.; Jeminet, G.; Gourcy, J.-G.; Dauphin, G. Tetrahedron: Asymmetry 1993, 4, 2101-2108; For related compounds see: (b) Chan, J. Y. C.; Hough, L.; Richardson, A. C. J. Chem. Soc., Perkin Trans. 1 1985, 1457-1462; (c) Chan, J. Y. C.; Hough, L.; Richardson, A. C. J. Chem. Soc., Chem. Commun. 1982, 1151-1153.

7. Compounds $\mathbf{1 a}, \mathbf{b}$ were compared with authentic samples available in our laboratory. For spectral data see Refs. 4 and 5 .

8. For reported synthesis of $\mathbf{1 b}$ see: (a) Lastdrager, B.; Timmer, M. S. M.; Van der Marel, G. A.; Overkleeft, H. S. Tetrahedron Lett. 2005, 46, 6195-6198; (b) Sharma, A.; Iyer, P.; Gamre, S.; Chattopadhyay, S. Synthesis 2004, 1037-1040; (c) Smith, A. B.; Corbett, R. M.; Pettit, G. R.; Chapuis, J.-C.; Schmidt, J. M.; Hamel, E.; Jung, M. K. Bioorg. Med. Chem. Lett. 2002, 12, 2039-2042; (d) Hayes, P.; Suthers, B. D.; Kitching, W. Tetrahedron Lett. 2000,
41, 6175-6179; (e) Fan, X.; Flentke, G. R.; Rich, D. H. J. Am. Chem. Soc. 1998, 120, 8893-8894; (f) Crimmins, M. T.; Rafferty, S. W. Tetrahedron Lett. 1996, 37, 5649-5652; (g) Sauret, S.; Cuer, A.; Gourcy, J.-C.; Jeminet, G. Tetrahedron: Asymmetry 1995, 6, 1995-2000.

9. Lokey, R. S.; Mills, N. S.; Rheingold, A. L. Organometallics 1989, 8, 1803-1805, and references cited therein.

10. Alonso, F.; Meléndez, J.; Yus, M. Russ. Chem. Bull., Int. Ed. 2003, 52, 2628-2635, and references cited therein; For a work in spiroketal area using a similar approach see: Meléndez, J.; Alonso, F.; Yus, M. Tetrahedron Lett. 2006, $47,1187-1191$.

11. Friedman, L.; Shani, A. J. Am. Chem. Soc. 1974, 96, 71017103.

12. Compound 4 a was classically prepared, in a $83 \%$ vield, from commercially available $1,2-O$-isopropylidene-1,2,4butanetriol, by the action of carbon tetrabromide in the presence of triethylamine and triphenyphosphine in dichloromethane.

13. Nouguier, R.; Mignon, V.; Gras, J. L. J. Org. Chem. 1999, $64,1412-1414$.

14. Teregulova, G. T.; Rolnik, L. Z.; Zlot-Skii, S. S.; Rakhman-kulov, D. L.; Silishchev, N. N.; Sokolova, T. A.; Khazipov, R. Kh. J. Appl. Chem. USSR 1989, 1,15011504.

15. Olsen, R. K.; Hennen, W. J.; Wardle, R. B. J. Org. Chem. $1982,47,4605-4611$

16. Typical procedure for the preparation of $5 \mathrm{c}:$ a $1.5 \mathrm{M}$ solution of tert-BuLi in hexanes $(7 \mathrm{~mL}, 10.5 \mathrm{mmol})$ was added to THF $(6 \mathrm{~mL})$, cooled at $-78^{\circ} \mathrm{C}$. 4a $(1.20 \mathrm{~g}$, $5.65 \mathrm{mmol})$ in THF $(5 \mathrm{~mL})$ was dropwise added and the reaction mixture was stirred at the same temperature for $1 \mathrm{~h} 30 \mathrm{~min}$ then allowed to return to $-10^{\circ} \mathrm{C}$. To a slurry of ultra-pure copper iodide ( $558.0 \mathrm{mg}, 2.93 \mathrm{mmol}$ ) in THF $(20 \mathrm{~mL})$ cooled to $-40{ }^{\circ} \mathrm{C}$ under argon was added the previously prepared solution of 1,2-O-isopropylidene-4lithio-1,2-butanediol in pentane $(\sim 5.65 \mathrm{mmol})$. After $1 \mathrm{~h}$ at $-40^{\circ} \mathrm{C}$, the resultant solution was cooled to $-65^{\circ} \mathrm{C}$, and a solution of $7(275.2 \mathrm{mg}, 1.25 \mathrm{mmol})$ in THF $(6 \mathrm{~mL})$ was added dropwise over $25 \mathrm{~min}$. The reaction was stirred for an additional hour at $-65^{\circ} \mathrm{C}$ then warmed slowly to $-40^{\circ} \mathrm{C}$ over $2 \mathrm{~h}$, and allowed to return to rt overnight. An aqueous saturated solution of ammonium chloride $(15 \mathrm{~mL})$ was added and the layers were partitioned. The aqueous layer was extracted with ether $(3 \times 5 \mathrm{~mL})$. The combined organic extracts were washed with brine $(2 \times 5 \mathrm{~mL})$, dried over $\mathrm{MgSO}_{4}$, filtered and concentrated under reduced pressure. Further purification by flash chromatography (cyclohexane/EtOAc 95:1-4:1) gave 5c ( $121.0 \mathrm{mg}, 0.38 \mathrm{mmol}, 30 \%$ ) as a colourless oil.

17. Spectroscopic data for 1c: viscous oil; $\mathrm{IR}(\mathrm{NaCl}$, neat), $v$ $3605,3449,2951,2873,2853,1452,1437,1418,1363,1304$, $1246,1240,1234,1229,1221,1216,1210,1188,1177,1158$, $1133,1102,1071,1050,1034,1020,1009,966,945 ;{ }^{1} \mathrm{H}$ NMR $\left(400 \mathrm{MHz}, \mathrm{CDCl}_{3}\right) \delta 4.06$ (dddd, $1 \mathrm{H}, J=11.0,5.0$, $4.0,3.0 \mathrm{~Hz}, \mathrm{H}-2), 3.80(\mathrm{dd}, 1 \mathrm{H}, J=11.0,3.0 \mathrm{~Hz}, \mathrm{H}-3 \mathrm{eq}$ ), $3.80-3.52\left(\mathrm{~m}, 5 \mathrm{H}, \mathrm{H}-8,2 \times \mathrm{CH}_{2} \mathrm{OH}\right), 3.62(\mathrm{~d}, 1 \mathrm{H}$, $\left.J=11.5 \mathrm{~Hz}, \mathrm{H}-5_{\mathrm{eq}}\right), 3.45\left(\mathrm{t}, 1 \mathrm{H}, J=11.0 \mathrm{~Hz}, \mathrm{H}-3_{\mathrm{ax}}\right)$, $3.31\left(\mathrm{~d}, 1 \mathrm{H}, J=11.5 \mathrm{~Hz}, \mathrm{H}-5_{\mathrm{ax}}\right), 2.89$ (bs, $\left.1 \mathrm{H}, \mathrm{OH}\right), 2.27$ $(\mathrm{t}, 1 \mathrm{H}, J=6.0 \mathrm{~Hz}, \mathrm{OH}), 1.92(\mathrm{td}, 1 \mathrm{H}, J=13.5,4.0 \mathrm{~Hz}$, $\left.\mathrm{H}-10_{\mathrm{eq}}\right), 1.66\left(\mathrm{~m}, 1 \mathrm{H}, \mathrm{H}-10_{\mathrm{ax}}\right), 1.58-1.50\left(\mathrm{~m}, 1 \mathrm{H}, \mathrm{H}-9_{\mathrm{eq}}\right)$, $1.54\left(\mathrm{~m}, 1 \mathrm{H}, \mathrm{H}-11_{\mathrm{eq}}\right), 1.36-1.25\left(\mathrm{~m}, 2 \mathrm{H}, \mathrm{H}-11_{\mathrm{ax}}, \mathrm{H}-9_{\mathrm{ax}}\right)$; ${ }^{13} \mathrm{C} \mathrm{NMR}\left(100 \mathrm{MHz}, \mathrm{CDCl}_{3}\right) \delta 94.0$ (C6), 72.1 (C5), 70.6 (C8), $68.1(\mathrm{C} 2), 67.3(\mathrm{C} 3), 65.9\left(\mathrm{CH}_{2} \mathrm{OH}\right), 62.4\left(\mathrm{CH}_{2} \mathrm{OH}\right)$, 30.5 (C11), 26.1 (C9), 17.4 (C10); HRMS (ES+) 241.1049 (calcd 241.1052); $[\alpha]_{\mathrm{D}}^{22}+43.1\left(c 1.10, \mathrm{CHCl}_{3}\right)$. 